\title{
The rationality of decisions in the university professors' inter-professional transitions
}

\author{
Elza fátima Rosa Veloso ${ }^{1}$ \\ JOEl SOUZA DUTRA ${ }^{2}$ \\ RODRIGO CUNHA DA SILVA ${ }^{3}$ \\ LEONARDO NELMI TREVISAN ${ }^{4}$
}

\author{
${ }^{1}$ Fundação Instituto de Administração (FIA) / Mestrado Profissional em Gestão de Negócios, SÃo Paulo - SP, Brazil \\ 2 Universidade de SÃo PaUlo (USP) / FACUldade de EConomia, AdMInIstração e Contabilidade, Programa de Pós-Graduação em \\ AdMINISTRAÇÃO, SÃO PAULO - SP, BRAZIL \\ 3 Universidade Anhembi Morumbi / Mestrado Profissional em Gestão de Alimentos e Bebidas, São Paulo - SP, Brazil \\ 4 Pontifícia Universidade Católıca de SÃo Paulo (PuC-SP) / Programa de Pós-Graduação em AdministraçÃo, SÃo PaUlo - SP, Brazil
}

\begin{abstract}
This article presents a study analyzing the rationality of the decisions made by university professors in their transition from other professions to the teaching career. The study analyzed 357 respondents who understand to have changed professions when deciding to pursue a career as a higher education professor. Four hypotheses were evaluated, establishing links among the influence of the previous profession, the transition drivers, the attributes of the transition, and the resources triggered by the individual on the rationality of their decisions. The results showed that attributes and resources influence rational decisions and choices that extrapolate rationality. Also, the lower workload in the current profession allows the person to identify more positively the attributes of the experienced transition. Finally, the perception of uncertainty in the previous profession leads to more emotional decisions and are more influenced by variations in the context. Overall, while current studies strongly consider emotion in the decision-making process, the findings point out that balancing rationality and subjectivity is important to reduce future frustration in career decisions.
\end{abstract}

Keywords: Career transition. Career decisions. Career management. Mid-career crisis. Career rationality.

\section{A racionalidade das decisões na transição interprofissão de professores universitários}

\begin{abstract}
This article presents a study analyzing the rationality of the decisions made by university professors in their transition from other professions to the teaching career. The study analyzed 357 respondents who understand to have changed professions when deciding to pursue a career as a higher education professor. Four hypotheses were evaluated, establishing links among the influence of the previous profession, the transition drivers, the attributes of the transition, and the resources triggered by the individual on the rationality of their decisions. The results showed that attributes and resources influence rational decisions and choices that extrapolate rationality. Also, the lower workload in the current profession allows the person to identify more positively the attributes of the experienced transition. Finally, the perception of uncertainty in the previous profession leads to more emotional decisions and are more influenced by variations in the context. Overall, while current studies strongly consider emotion in the decision-making process, the findings point out that balancing rationality and subjectivity is important to reduce future frustration in career decisions.
\end{abstract}

Keywords: Career transition. Career decisions. Career management. Mid-career crisis. Career rationality.

\section{La racionalidad de las decisiones en la transición interprofesión de profesores universitarios}

\section{Resumen}

El estudio presentado en este artículo tuvo como objetivo analizar la racionalidad de las decisiones tomadas por profesores universitarios, en su transición de otras profesiones a la carrera docente. Se analizaron 357 encuestados, que consideraron haber cambiado de profesión en la época en que decidieron seguir la carrera de docentes de nivel superior. Se evaluaron cuatro hipótesis relacionando la influencia de la profesión anterior, de los impulsores de la transición, de los atributos de la transición y de los recursos accionados por el individuo sobre la racionalidad de sus decisiones. Los resultados mostraron que los atributos y los recursos influencian tanto las decisiones racionales como las que van más allá de la racionalidad; la menor carga de trabajo en la profesión actual permite que la persona identifique más positivamente los atributos de la transición que ha vivido; la percepción de la incertidumbre en la profesión anterior lleva a decisiones más emocionales y más condicionadas a variaciones contextuales. En general, aunque los estudios actuales consideren fuertemente la emoción en el proceso decisorio, para evitar frustraciones futuras es importante equilibrar la racionalidad y la subjetividad en las decisiones de carrera.

Palabras clave: Transición de carrera. Decisiones de carrera. Gestión de carrera. Crisis de la media carrera. Racionalidad en la carrera.

ArArticle submitted on December 21, 2018 and accepted for publication on July 11, 2019.

[Translated version] Note: All quotes in English translated by this article's translator.

The authors thank FAPESP- Foundation for Research Support of the State of Sao Paulo (aid 2012/21432-3), PPGA-FEA-USP and PROGEP-FIA for supporting the research of postdoctoral/habilitation of the first author of this Articl.

DOI: http://dx.doi.org/10.1590/1679-395177946x 


\section{INTRODUCTION}

The study presented in this article aimed to analyze the rationality of the decisions taken by university professors in their transition from other professions to the teaching career. Since, according to Clarke (2013), career transitions are influenced by several factors, including national, cultural and political environments, only Brazilian teachers were involved in this study.

Considering the Brazilian context, Kilimnik, Reis Neto, Santos et al. (2015) claimed that higher-level teaching is an activity of great importance to society, while Freire and Fernandez (2015) highlighted the need to expand studies about university professors. The attractiveness of the academic career in Brazil is evident in the search for teacher training courses.

In 2014, the country had 383,386 professors in higher education, according to the most complete and recent Technical Summary with consolidated data from the Ministry of Education. Between 2004 and 2014, the number of professors with doctoral degrees practically doubled, with an increase of $98.7 \%$, jumping from 22,023 to 43,531 in the private sector higher education institutions, and from 41,221 to 90,963 in the public sector institutions. At the master's degree, the numbers jumped from 63,712 to 103,570 cases in the private sector and from 22,614 to 46,963 cases in the public sector (INEP, 2016).

Since the 1990s, the transition from other professions to higher-level teaching has been characterized by the image that, in the academic environment, the professional is subject to permanently changing stimuli and is seen with "autonomy and responsibility" (KILIMNIK, OLIVEIRA, SANT'ANNA et al., 2006). The relevance of autonomy and interactive process, which occurs more easily in the classroom, was also recognized by Paiva and Melo (2009) as an important incentive in the transition from a position in a company to a teaching career.

The image of autonomy inherent to the teaching career in contrast to the greater hierarchical control in the business field, is at the core of the idealization in the transition process. Oliveira, Kilimnik and Oliveira (2013) stated that there is a duality between working in companies and teaching, reflected by the opposition between "heaven and hell" in the perception of professors who were former executives. For them, the classroom is considered "magic," a differentiated space, in which recognition would be perennial. The academic context has a consolidated image of "the world of knowledge and ideas," while the business scenario is regarded as "the world of the market." The student body is regarded as made of persons who have "different experiences" and are not regarded as "machines or computers." The authors explain that the effects of globalization on the "organizational world" are at the origin of the idealized image of executives about the "academic world."

In order to understand the transition from other professions to higher-level teaching, it is important to highlight the fact that career transitions promote the change of professional identity (IBARRA, 2009). Considering career transition "the period during which an individual is changing and redirecting his or her functions or orientations," Louis $(1980$, p. 338) identified in the transitions between functions (or roles), the "inter-professional transitions", which are addressed on this study, leading people to assume functions or roles different from the previous ones.

By making the association between career decision and career transition theories, Veloso and Dutra (2014) supported their arguments about the importance of studying these theories in an aggregate way in the fact that transitions involve decisions, and that decisions involve transitions. Career decisions have a great impact upon the lives of people and are among the most important choices of an individual (JUNG, PARK and RIE, 2015; VERBRUGGEN and VOS, 2016). Explicitly or implicitly, studies on career decisions focus on transitions (VERBRUGGGEN and VOS, 2016). Hence the importance, for the field of career management, of associating theories and concepts involved in these two themes, also considering the statement of Barley, Bechky and Milliken (2017) that it is surprising to see the lack of studies about the phenomena involving the transformations undergone by work and on changes in the way we work.

In view of these reflections, this article, which involves the use of decision and career transition theories to observe the way the movement between professions takes place, might contribute to the understanding of the transformations being currently experienced by work. 


\section{THEORETICAL FRAMEWORK}

This session presents the concepts that supported the elaboration of the hypotheses and methodology upon which the research field was based.

\section{Career decisions}

Hartung and Blustein (2002) attribute to Parsons (1909) the initial development of the career decision theory. Parsons described the main factors present in the process of choosing a vocation, which would be the greatest decision in the life of a person. In his view, in practice, in order to help people in their decision-making, counselors should be based on the following three guidelines, in a sequential manner, in which the person should: 1) "know himself or herself"; 2 ) "know the world of work"; and 3) "connect these two groups of knowledge rationally." Parsons named this third orientation true reasoning.

According to Hartung and Blustein, when developing and testing hypotheses, theorists and researchers almost invariably use one or more of the elements raised by Parsons. These authors stated that the model of Parsons would be the first formal career decision-making model, with several researchers (e.g. KRUMBOLTZ, 1998; PHILLIPS, 1994, 1997) trying to interpret true reasoning, with these interpretations enabling the possibility of evolution of alternative models.

According to Murtagh, Lopes and Lyons (2011) career decision-making models might be divided into three constructs, the first of which is "the rational models", which originate from the expected utility models, in which decisions are made in search of an optimal result. These models might be analyzed through the scientific and normative models. In the scientific model, which is based on Gelatt (1962), decisions are systematic and sequential. The normative model, in which the decisions consider all possible alternatives, is based on the works of Katz (1966), Pitz and Harren (1980), Gati and Asher (2001) (MURTAGH, LOPES and LYONS, 2011).

The normative models, according to Murtagh, Lopes and Lyons (2011), were criticized by several authors. Kahneman, Slovic and Tversky (1982) stated that people may fail to follow the prescribed process, for example, when they do not consider all the options or misjudge the possibilities of the events. Gati (1986) criticized the need to quantify productivity and valence, and then to calculate the product for a very large set of alternatives, stating that this process exceeded the cognitive capacity of individuals. These criticisms led to the study of a second decision model category (MURTAGH, LOPES and LYONS, 2011).

The second category is that of the "normative models that recognize the cognitive processes." These models consider the cognitive information processing approach, in which decisions are focused on the interests, skills, values, and also employment opportunities (PERDUE, REARDON and PETERSON, 2007). According to Murtagh, Lopes and Lyons (2011), other models are also considered in this category. In the sequential elimination models, which are based on the works of Janis and Mann (1977) and Simon (1955), the decisions recognize human cognition in the search for "only satisfactory" options. The prescriptive, deep exploration, and choice models are based on Gati and Asher (2001) and involve decisions based on the strategy of previous elimination of options, not corresponding to aspects of the desired result.

The third category is that of "perspectives that go beyond rational models". Rationality is extrapolated and psychology approaches are taken into account, considering that decisions are not sequential and systematic, but often creative. In this view, context and chance are important factors in the choices, recognizing opportunities, and attributes of the person who is making the decision. Thus, the decision would follow its own path, emphasizing emotional and cognitive processes (MURTAGH, LOPES and LYONS, 2011).

\section{Career management and the context of transitions}

The evolution of career studies indicated, in the late 1990s and early 2000s, that organizational careers - those designed to consider a single employment scenario - would give room to boundaryless careers, which transcend organizational boundaries, and protean careers, which consider success as something "internal to the individual" or "psychological" (ARTHUR and ROUSSEAU, 1996; ARTHUR, INKSON and PRINGLE, 1999; HALL, 2002). 
According to Veloso and Dutra (2011), the conceptions of protean and boundaryless careers are two ways of theoretically considering the social and organizational changes that have brought about the need for the person to manage his or her own career. Kostal and Wiernik (2017) claimed that these conceptions have dominated research over the last two decades, being considered "the new career," a concept that emerges in the globalized economy and considers a significant change in the psychological contract between employees and companies.

Since authors like Kostal and Wiernik (2017) have not dissociated new careers from the business context, it is important to consider the opinion of Clarke (2013), who questioned at the beginning of this decade the trends which pointed out in the 2000 s that organizational careers would lose their place in society. Upon analyzing them, Clarke promoted a systematization of reasoning that provided five propositions, considering that such careers: 1) may be flexible, challenging, and mobile; 2) provide opportunities for employee development; 3) may be managed together; 4) promote balanced relationships; and 5) may hinder mobility.

The author concluded her reflections proposing a model for the new organizational career, which combines characteristics of the traditional organizational careers, boundaryless careers, and protean ones. She presented the results from many studies, carried out in several countries, which provided evidence that "the organizational career is alive, and well" (CLARKE, 2013, p. 688).

The view of Clarke is corroborated by the study by Veloso and Dutra about career transition. It was found that both the employees who were laid off and those who remained working in a financial institution after the privatization process experienced a major transition in their careers. These authors explained that "not even professions previously considered safe might be regarded as unattainable" (VELOSO and DUTRA, 2011, p. 850).

In view of the reflections held in this session, the first hypothesis of this study was elaborated, which considers the previous profession of the respondents:

Hypothesis 1 - There is a direct positive influence of the perception regarding the previous profession upon the rationality of decisions regarding the inter-professional transition.

\section{The career transition and the mid-career crisis}

Currently, career transitions are so frequent that studies on this subject seek to reconcile several perspectives. Skilton and Bravo (2017), for example, mentioned the risk perceived in the transition opportunity as the central factor in the emergence of change intentions. Super (1990), using the theory of human development, proposed the analysis of life stages, leading to new understandings about career development. Oliveira, Melo-Silva and Collection (2012, p. 225) explained that the model of Super had as central issues "the social roles, living spaces, and stages of development, which emphasize the concepts of maturity and/or adaptability of careers."

In terms of adaptability, Horst, Klehe, and Heijden (2017) explain that, faced with imminent transitions, workers need to adapt their careers, mastering challenges and remaining curious about professional options and alternatives. These authors consider, among other individual variables, age as an important influencer of adaptive responses. The study by Maddox-Daines (2016) on women managers in the mid-career phase, around 45 years old, revealed the importance of balancing personal and professional life, and of recognizing the need for commitment to achieve career balance.

These recent studies (MADDOX-DAINES, 2016; HORST, KLEHE and HEIJDEN, 2017) highlighted the growing recognition of career intrinsic factors as age progresses. These reflections allow us to consider that, according to Veloso (2012), one of the causes of professional transition might be the mid-career crisis, when the person is in the mid-career transition, at the age of 40 .

In a broader sense, this crisis may include people who started their careers still young and have restarted studying at the age of 30, or workers in their 50s who experience new career perspectives, sometimes with more flexibility, seeking for different ways of living in the future (IBARRA, 2009). Morison, Erickson and Dychtawald (2006, p. 2) mentioned that restlessness in the middle of the career is old, but its manifestations change with each generation, and today this crisis affects harder professionals with the following sources of frustration:

- Career bottleneck - competition that worries workers in the 40 to 50 year age group. 
- Work/life tension - need to balance work with obligations to children and parents.

- Lengthening horizon - people who have spent a lot and accumulated little need to work for many years.

- Skills obsolescence - some struggle to adjust to new ways of working, and others expect working time to lead them to grow in their careers.

- Disillusionment with employer - lack of confidence due to staff cuts or resentment of wage differences between positions.

- Burnout - exhaustion, stress, boring and repetitive work, low energy.

- Career disappointment- when the role and impact of work do not correspond to the ideals and ambitions of youth.

It should be noted that the age of the mid-career crisis may presents a large variation (IBARRA, 2009), since the age of the career currently counts more than the chronological age of the person (HALL, 1996, 2002). In view of this possibility, the sources of frustration pointed out by Morison, Erickson and Dychtawald (2006) were considered as drivers of the inter-professional transition, which are treated in an aggregate form in the second hypothesis of this study.

At this point, it is important to point out that, when addressing such sources of frustration, Veloso (2012) mentioned the work of Morison, Erickson and Dychtawald (2006) to explain that some people, when going through transitions associated with the mid-career crisis, have particular and subjective impulses confused with changes in context that reach all careers and that also drive transitions.

At this point, it is important to point out that in addressing such sources of frustration, Veloso (2012) mentions the work of Morison, Erickson and Dychtawald (2006) to explain that some people, when going through transitions associated with the mid-career crisis, have particular and subjective impulses confused with changes in context that affect all careers and that also drive transitions.

Hypothesis $\mathbf{2}$ - There is a direct positive influence of the transition driving factors upon the rationality of decisions regarding the inter-professional transition.

\section{The professional role transition and its attributes}

According to Louis (1980), people go through job transitions (or roles) when they enter or return to the workforce, take on a different role within the same organization, move from one organization to another, change professions, or leave the workforce. The transition of professional role was addressed by Nicholson and West (1989), which defined it as any major change in function or work context.

This type of transition was addressed by Maree (2014), who considered adaptability to be a segment of the construction of career theories. This author explained that adaptability, addressed by Super (1990), has a strong relationship with personal development actions, role transitions, and strategies to face the several transitions and rapid technological changes. Maree explained that Savickas $(1997,2008)$ regarded it as essential to cope with the transitions faced by career advisors, and in an appropriate way, with the changes that also occur in their own lives.

According to Ashforth (2001), the role transition is a major challenge. Regarding the nature of the changes, the author stated that individuals may suffer "micro transitions", which are changes in everyday life, or "macro transitions," which are roles adopted or discarded during life and which may (or not) be consistent with their career histories.

In the study presented in this article, the focus is on macro transitions which, according to Ashforth, might present the following attributes: 1 ) low magnitude versus high magnitude; 2 ) socially desirable versus socially undesirable; 3 ) voluntary versus involuntary; 4) predictable versus unpredictable; 5) collective versus individual; 6) long-lasting versus short-lasting; 7) reversible versus irreversible. These attributes are presented in scales, as a continuum, and discussed in terms of their impact on the difficulty and on the valence of the transition represents to the individual.

Usually, according to Ashforth, transitions present both negative and positive qualities, and the attributes affect the difficulty and valence of the professional role transition. This author stated that difficulty tends to be reciprocally related to negative valence. It is understood, then, that a transition will generally be easier and will present more positive valence if it is of low magnitude, long duration, socially desirable, voluntary, predictable, collective, and reversible. The attributes raised by Ashforth allowed the elaboration of the third hypothesis of this study:

Hypothesis 3 - There is a direct positive influence of the attributes of transitions upon the rationality of decisions regarding the inter-professional transition. 


\section{Resources to deal with the transition}

Anderson, Goodman, and Schlossberg (2012) claimed that transition is an event or a "non-event" that results in changes in relationships, routines, assumptions, and roles. "Non- events" are situations that one expects to happen and that have not occurred - for example, a promotion, whereas events are concrete situations of change. The view of the authors is represented by a model, System 4S (Situation; Self; Social Support; Strategies), which offers a way to identify potential resources triggered by the individual to deal with the transition, and considers the following factors:

- Situation - involves what is happening and the possibility of association of transition with multiple stressors.

- Self - involves the one that is experiencing the transition and considers that each person is different in terms of needs and personality.

- Social Support - involves the aids available for transition and is often referred to as the key to dealing with stress.

- Strategies - involve the way a person handles the transition.

The resources, represented by these four factors (4S), according to Anderson, Goodman and Schlossberg (2012), explain the difference between people in the way they handle career transitions. Also dealing with resources, Hartung and Blustein (2002) explained the view of Parsons (1909) in building theory, research, and practice on career decisions. Parsons observed the need for the person to understand his/her own resources in order to make the decision, as a part of a clear understanding that the individual needs to have about himself or herself. These reflections supported the elaboration of the fourth hypothesis of this study:

Hypothesis 4 - There is a direct positive influence of the resources triggered by people upon the rationality of decisions regarding the inter-professional transition.

\section{METHODOLOGY}

A survey was conducted, in which people provided information about their behavior, beliefs, and values (GIL, 2010; SELTIZ, WRIGHTSMAN and COOK, 2007). For the elaboration of the research instrument, five PhD professors from different institutions, experts in people management, were invited to participate in a face-to-face meeting for structured methodological discussion. On that occasion, the discussion took place in the focal group format, lasting for three hours.

After this procedure, in order to validate the methods and the research instrument, with its 56 statements, using a Likerttype five-point scale, a pre-test was performed with 14 professors and then final adjustments were made. In the Appendix (Table A), standardized factorial loads of the evaluated statements were exposed, and those highlighted in dark and coded were the 29 used in the final measurement model, with values above 0.4 or -0.4 .

The sample consisted of 379 university professors who underwent inter-professional transition. The main criterion for selection was that the person thought to have changed profession when he/she sought an academic career and had started to consider the higher-level teaching as his/her main profession. The size of the population could not be circumscribed, so a non-probabilistic sample was adopted, selected for convenience (GIL, 2010; SELTIZ, WRIGHTSMAN and COOK, 2007).

As for the elaboration of the research instrument, constructs present in the literature about decision and career transition were initially identified. Then, indicators were developed which were the basis for the elaboration of the 56 statements of the collection instrument. Box 1 shows the path followed in this step. 
Box 1

Relationship among constructs, indicators and affirmatives

\begin{tabular}{|c|c|c|c|}
\hline Constructs & Indicators & Reference & Assertive (example) \\
\hline Previous profession & $\begin{array}{l}\text { Overview } \\
\text { Flexibility } \\
\text { Development } \\
\text { Sharing } \\
\text { Balance } \\
\text { Mobility }\end{array}$ & Clarke (2013) & $\begin{array}{l}\text { Statement: In my previous profession... } \\
\text { I felt insecure professionally. }\end{array}$ \\
\hline Drivers & $\begin{array}{l}\text { Career bottleneck } \\
\text { Work/life tension } \\
\text { Lengthening horizon } \\
\text { Skills obsolescence } \\
\text { Disillusionment with } \\
\text { employer } \\
\text { Burnout } \\
\text { Career disappointment }\end{array}$ & $\begin{array}{l}\text { Morison, } \\
\text { Erickson and } \\
\text { Dychtawald } \\
(2006)\end{array}$ & $\begin{array}{l}\text { Statement: I changed my profession because... } \\
\text { I felt disappointed with the employer. }\end{array}$ \\
\hline Transition attributes & $\begin{array}{l}\text { Magnitude } \\
\text { Social desirability } \\
\text { Voluntarism } \\
\text { Predictability } \\
\text { Collectivity } \\
\text { Duration } \\
\text { Reversibility } \\
\text { Difficulties } \\
\text { Valence }\end{array}$ & $\begin{array}{l}\text { Ashforth } \\
(2001)\end{array}$ & $\begin{array}{l}\text { Statement: As for my change of profession, I feel } \\
\text { that... } \\
\text { The change was planned by me. }\end{array}$ \\
\hline $\begin{array}{l}\text { Resources to deal } \\
\text { with the transition }\end{array}$ & $\begin{array}{l}\text { Situation } \\
\text { Self } \\
\text { Social Support } \\
\text { Strategies }\end{array}$ & $\begin{array}{l}\text { Anderson, } \\
\text { Goodman and } \\
\text { Schlossberg } \\
(2012)\end{array}$ & $\begin{array}{l}\text { Statement: As for the way I faced my change of } \\
\text { profession, I realize that... } \\
\text { I supported people I could trust. }\end{array}$ \\
\hline $\begin{array}{l}\text { Decisions in } \\
\text { the transition }\end{array}$ & $\begin{array}{l}\text { Rational } \\
\text { Rational/cognitive } \\
\text { Extrapolate rationality }\end{array}$ & $\begin{array}{l}\text { Murtagh, } \\
\text { Lopes and } \\
\text { Lyons (2011) }\end{array}$ & $\begin{array}{l}\text { Statement: To decide to change profession... } \\
\text { I took attitudes that followed a logical sequence. }\end{array}$ \\
\hline
\end{tabular}

Source: Elaborated by the authors.

For the collection of responses, a research assistant contacted people who were on lists of professors from various higher education institutions which provided the access for the researchers. When a respondent was found to be suitable to the characteristics of the work population, the assistant requested the answer to the electronic questionnaire and the indication of new respondents with the same profile.

As shown in Box 2, preliminary, univariate, bivariate, and multivariate statistical analyzes were applied to assess the quality of the structural measurement model. In the analysis of the responses obtained, significant multivariate cases were assessed by the Mahalanobis distance and excluded from the analysis. The randomness of the omissions of the respondents was also observed; and therefore the missing data were also excluded. Finally, the normality of the variables was evaluated. After this preliminary stage, of the 379 total respondents, 22 were excluded, resulting in a sample of 357 for further analyzes. 


\section{Box 2}

\section{Statistical analyzes used in the search}

\begin{tabular}{|c|c|c|}
\hline Technique & Objective of the technique & Premises \\
\hline Analysis of missing values & $\begin{array}{l}\text { To analyze the cases omitted as to their frequency and } \\
\text { systematicity. }\end{array}$ & \\
\hline Z score analysis & Detect the presence of extreme univariate cases. & - Scale reason. \\
\hline Kolmogorov-Smirnov test & $\begin{array}{l}\text { To verify the univariate normality in order to choose } \\
\text { the inclusion of the variables in the factorial analysis. }\end{array}$ & $\begin{array}{l}\text { - Scale reason. } \\
\text { - KS test- HO: Distribution is } \\
\text { normal; desirable not to reject } \\
\text { HO; significance level: } 5 \%\end{array}$ \\
\hline $\begin{array}{l}\text { The distance calculation from } \\
\text { Mahalanobis is }\end{array}$ & Detect the presence of extreme univariate cases. & $\begin{array}{l}\text { - Scale reason. } \\
\text { - Normality. } \\
\text { - linearity. }\end{array}$ \\
\hline Pearson's correlations & $\begin{array}{l}\text { To check the multicollinearity and linearity between } \\
\text { the variables related to the statements about the } \\
\text { perception of the working environment for factorial } \\
\text { analysis. }\end{array}$ & $\begin{array}{l}\text { - Scale reason. } \\
\text { - univariate normality. }\end{array}$ \\
\hline Frequencies analysis & $\begin{array}{l}\text { The profile characterization data of the respondents } \\
\text { were tabulated. }\end{array}$ & \\
\hline $\begin{array}{l}\text { Student " } \mathrm{t} \text { " test and } \\
\text { Anova: Techniques used } \\
\text { to determine the mean } \\
\text { difference of a dependent } \\
\text { variable, considering two or } \\
\text { more independent categorical } \\
\text { variables. }\end{array}$ & $\begin{array}{l}\text { To investigate the existence of differences in response } \\
\text { patterns, according to the sociodemographic profile of } \\
\text { respondents. }\end{array}$ & $\begin{array}{l}\text { - Multivariate distribution of } \\
\text { the dependent variables close } \\
\text { to normality. } \\
\text { - Not existing excessive } \\
\text { multicollinearity among the } \\
\text { variables. } \\
\text { - linearity of the relationships } \\
\text { among the variables. } \\
\text { - desirable normality. }\end{array}$ \\
\hline Exploratory factorial analysis & $\begin{array}{l}\text { It seeks to explore the data and the relationship } \\
\text { between a set of variables, identifying correlation } \\
\text { patterns. }\end{array}$ & \multirow{3}{*}{$\begin{array}{l}\text { - Scale reason. } \\
\text { - It does not need } \\
\text { standardization. } \\
\text { - Absence of extreme cases. } \\
\text { - Correlation among variables. } \\
\text {-Linearity of the } \\
\text { inter-relationships. } \\
\text { - Desirable, but unavoidable } \\
\text { normality for large samples. }\end{array}$} \\
\hline Confirmatory factorial analysis & $\begin{array}{l}\text { Validate the statistical adequacy of the constructs to } \\
\text { the theory that is the basis of the research. }\end{array}$ & \\
\hline Structural model path analysis & $\begin{array}{l}\text { To analyze the relationship among the constructs, by } \\
\text { testing the hypotheses of the research. }\end{array}$ & \\
\hline
\end{tabular}

Source: Elaborated by the authors.

When analyzing Box 2, it is important to consider that there are two types of factorial analysis: the exploratory (AFE) and the confirmatory (AFC) analyses. Generally, AFE is used in the earliest stages of the research to explore the data. In this phase, the aim is to explore the relationship between a set of variables, identifying correlation patterns. In turn, AFC is used when the researcher is guided by a theory, testing to what extent certain variables are representative of a concept. "This technique does not assign variables to factors. Instead, the researcher must be able to make this designation before any results can be obtained." This is an adequate technique for verifying the validity of measurement scale construct, that is, "the degree to which a set of measured items actually reflects the theoretical latent construct that those items should measure" (HAIR JUNIOR, BLACK, BABIN et al., 2009, p. 590-591). 
In turn, AFC is used when the researcher is guided by theory, testing to what extent certain variables are representative of a concept. "This technique does not assign variables to factors. Instead, the researcher must be able to make this designation before any results are obtained." This is a suitable technique for checking the validity of measurement scale constructs, i.e., "the degree to which a set of measured items actually reflects the theoretical latent construct that those items should measure" (HAIR JUNIOR, BLACK, BABIN et al., 2009, p. 590-591).

Both AFE and AFC were considered to be adequate for the purposes of this study, in view of the theoretical framework to identify factors in the working environment. Cronbach's Alpha was also calculated to verify the reliability of the measurement instrument, based on its internal consistency. In other words, it was tried to verify that the variables that propose to measure these factors produce similar results (HAIR JUNIOR, BLACK, BABIN et al., 2009).

It was considered that both the EAF and the AFC are adequate for the purposes of this study, in view of the theoretical framework to identify factors of the working environment. The Cronbach alpha was also calculated to check the reliability of the measurement instrument, based on its internal consistency. In other words, we have tried to check whether the variables that intend to measure these factors produce similar results (HAIR JUNIOR, BLACK, BABIN et al., 2009).

In the modeling of structural equations, there are several indexes that evaluate the quality of adjustment of the model to the data and the relationship between the constructs. However, there are no indices considered ideal for evaluating a given model. Therefore, in the overall assessment of the model, it is important to have an overview of the various indices, not being restricted to a particular one. Then, three absolute adjustment indices ( $X^{2}, \mathrm{GFI}$, and RMSEA) and two incremental adjustment indices (CFI and TLI) were used. The means of the answers of the five constructs of the research were also used, and univariate analysis (ANOVA) and Student's T test were performed, considering the different characteristics of the profile of the respondents (HAIR JUNIOR, BLACK, BABIN et al., 2009).

\section{ANALYSIS OF RESULTS}

In the elaboration of hypotheses, there was no intention to restrict the sample in terms of age. However, the average age was 40 years old, representing a sample that is consistent with the period of the greatest incidence of the mid-career crisis, according to Icara (2009) and Morison, and Erickson and Dychtawald (2006). Profile data indicate that $72 \%$ of respondents are over 41 years old and $63 \%$ of respondents are male. It is noteworthy that more than $70 \%$ of respondents left the previous profession and started in the current profession at the beginning of this century, indicating the recent nature of this transition phenomenon. Most of them (54.5\%) work from 21 to 40 hours; only $17.5 \%$ work more than 40 hours a week; $40 \%$ of them have a master's degree and $34 \%$ doctorate, and $48 \%$ also have another paid activity.

The areas of knowledge in which respondents work in the teaching career are: administration (73.32\%); psychology (4.58\%); education (4.04\%); accounting (3.77\%); economics (3.23\%); information technology (2.43\%); law (1.62\%); communication (1.35\%); engineering (1.35\%); and other areas (4.31\%).

In the initial descriptive analyzes, the dependent variables considered were the perception of the previous profession; transition drivers; transition attributes; resources to deal with the transition; and decisions in the transition.

The independent variables were gender; state in which the respondent works; time since he/she left the previous profession; type of position; bond; sector; type of company; schooling before the change. Among them, the only one that presented significant mean differences between the analyzed bands was the period that the person left the previous profession. The others did not present such differences $(p<0.05)$ in any of the five dependent variables of the research.

Regarding the time since the respondents left the previous profession, significant differences were observed in two variables: the one related to perception of the "previous profession" ( $F=2.49, p<0.05)$ and "drivers" $(F=6.80, p<0.01)$. In the variable about the "previous profession", respondents from the 2011 to 2015 presented a more positive means than respondents from 2001 to 2005 (2.70) and from 1975 to 2000 (2.64).

In the variable "drivers", respondents who left the previous profession between 2011 and 2015 presented a higher average (3.47) than those from 1975 to 2000 (3.22). It is then observed that, between 2011 and 2015, the "new organizational careers" of Clarke (2013) were probably already more consolidated in Brazil, and that the perception about the previous profession may have contributed to the decision of the respondents to change their profession. The drivers associated with 
the mid-career crisis (MORISON, ERICKSON and DYCHTAWALD, 2006) might also have become more meaningful to the public who has changed their profession more recently, as respondents who started working in the current profession between 2011 and $2015(F=5.72, p<0.01)$ also have higher averages (3.17) in the variable "thrust pieces" than the respondents from 1975 to 2000 (2.65) and from 2001 to 2005 (2.75).

Respondents aged 25 to 40 years have higher averages (2.99) than those aged over 50 years (2.71) for the variable "drivers" $(F=3.01, p<0.05)$. It is therefore observed that these impulses also made a difference to the younger age group, showing that the sources of frustration, which caused the mid-career crisis, may determine transitions from the age of 25.

The educational level also counts on the variable "drivers," since professionals with educational training up to the level of specialization, which was the lowest level measured in the research $(F=4.03, p<0.01)$, present a higher average (3.09) for this variable than those with post-doctorate (2.50).

People with a working hour of 1 to 10 hours per week have higher averages (3.21) for the variable "attributes" $(F=2.67$, $p<0.01$ ) than respondents who worked more than 40 hours (3.43). The attributes of Ashforth $(2001)$ - in this case those associated with transition planning - made more sense for respondents who have a lower workload.

\section{Measurement and structural model}

Table 1 shows the means, standard deviations, reliability indices, and correlations between all variables included in the study. These correlations evidenced the relevance of the proposed measurement model. It is noted that all variables exhibited significant correlations between the pairs.

Table 1

Mean, standard deviation, correlations, and reliability.

\begin{tabular}{lrrrccccc}
\hline \multicolumn{1}{c}{ Variable a } & M & DP & 1 & 2 & 3 & 4 & 5 \\
1- Previous profession & 3.32 & 0.60 & $\mathbf{0 . 6 0}$ & & & & \\
2- Transitional drivers & 2.82 & 0.84 & $0.50^{* *}$ & $\mathbf{0 . 7 1}$ & & & \\
3- Decisions in the transition & 2.93 & 0.44 & $0.40^{* *}$ & $0.61^{* *}$ & $\mathbf{0 . 6 7}$ & & \\
4- Transition attributes & 3.38 & 0.40 & $0.42^{* *}$ & $0.52^{* *}$ & $0.64^{* *}$ & $\mathbf{0 . 6 2}$ & & \\
5- Resources to deal with the transition & 4.08 & 0.44 & $0.47^{* *}$ & $0.37^{* *}$ & $0.41^{* *}$ & $0.50^{* *}$ & $\mathbf{0 . 7 7}$ & \\
\hline
\end{tabular}

Source: Elaborated by the authors.

Note:

$\underline{a}=357$. Cronbach $s$ Alpha reliability Indices $(\alpha)$ are diagonally across the matrix.

$\mathrm{M}=$ Mean; $\mathrm{DP}=$ standard deviation.

$* * p<0.01$

Based on the analysis of the results presented in Table 1, the presence of moderate correlation variables was observed. Therefore, at first, from the perception of respondents, the variables under analysis are correlated. The variables "drivers" and "resources to deal with the transition" have presented satisfactory Cronbach's alpha reliability indices (above 0.7), while the variables "previous profession", "decisions in the transition," and "attributes of the transition" are close to this parameter.

The highest average was that of the variable "resources to deal with the transition" (4.08), which indicates that the respondents have perceived the availability of resources in order to change profession. In turn, the lower average of the "drivers of the transition" (2.82) revealed a reduced perception about the effect of the impulses considered in this study on the transition. The mean of 3.38 and the lower standard deviation (0.40) of the variable of the "attributes of the transition" show less variability of responses about the decision being made voluntarily or unintentionally by the respondent. The averages of 3.32 and 2.93 for the variables "previous profession" and "decisions in transition," respectively, indicate a balance of discordant and concordant perceptions about these aspects of the this investigation.

Both EAF and the AFC were adequate for the purposes of this study, in view of the theoretical framework that aimed to identify the factors of the working environment. The Cronbach's alpha was also calculated to check the reliability of the measuring instrument, based on its internal consistency. In other words, we sought to check whether the variables that intend to measure these factors produce similar results (HAIR JUNIOR, BLACK, BABIN et al., 2009). 
The quality measurements of the exploratory factorial analysis KMO $(0.75)$, MSAs $(>0.5)$ and Bartlett's test $(p=0.01)$ were satisfactory, indicating the adequacy of this technique for the research variables.

The extraction of the factors was performed using the method of the main axes, with oblique rotation. It was possible to verify, by means of the eigenvalues $(>1)$, the probable existence of eighteen variables, an amount outside the initially foreseen in the theoretical model. Subsequently, we have tried to restrict the number of variables to the five variables supported by the theoretical framework of this study and by the validation performed with the experts in the pre-test phase of the instrument. The explained variance added to the five factors was 63.47.

In the overall assessment of the model, it is necessary to have an overview of the various indices, not being restricted to a particular one. The indices used in this study were three regarding of absolute adjustment ( $X^{2}, \mathrm{GFI}$, and RMSEA) and two of incremental adjustment (CFI and TLI). The value of the chi-square $\left(\mathrm{X}^{2}\right)$ was sensitive to large sample sizes and the number of variables observed, which may reduce the adjustment of a model for reasons that may not be truly detrimental to its overall validity. Therefore, in models that present between 12 and 30 observed variables and samples greater than 250, $p$-significant values might be expected (HAIR JUNIOR, BLACK, BABIN et al., 2009).

According to Hair Junior, Black, Babin et al. (2009), other commonly used absolute adjustment indices are goodness of fit Index $(\mathrm{GFI})$, whose reference value is 0.9 , and Root mean Square Error of approximation (RMSEA), with a reference value between 0.05 and 0.08 . The following incremental adjustment indices were used for comparison of competing models: Comparative fit Index (CFI), whose reference value is 0.9 ; and Tucker-Lewis Index (TLI), used to compare models with different variable numbers, in which models with smaller values are the most adjusted.

In Table 2, the adjustment statistics for the measurement model are presented. The indexes show that the proposed measurement adjustment obtained the following adjustment indices for the data: $X^{2}(1474, N=357)=3798.25, p 0.01$, $\left.\mathrm{X}^{2} / d f=2.58, \mathrm{GFI}=0.80, \mathrm{CFI}=0.75, \mathrm{RMSEA}=0.07, \mathrm{TLI}=0.65\right)$, with significant $\mathrm{X}^{2}$ value. Thus, the model was adjusted, selecting the commands with factor loads higher than 0.4 or -0.4 , representing a total choice of 29 statements among the 56 measured. The proportion of total respondents (357) by observed variables was of 12 respondents per statement, in accordance with the recommendations of Hair Junior, Black, Babin et al. (2009).

Table 2

Measurement model statistics

\begin{tabular}{lcccccccc}
\hline \multicolumn{1}{c}{ Measurement models tested } & $\chi^{2}$ & $D f$ & $\chi^{2} / d f$ & $\Delta \chi^{2}$ & GFI & CFI & RMSEA & TLI \\
\hline Five-factor model & $3798.25^{* *}$ & 1474 & 2.58 & -2741.0 & 0.80 & 0.75 & 0.07 & 0.65 \\
Five-factor model (adjusted) & $1057.25^{* *}$ & 393 & 2.69 & & 0.91 & 0.90 & 0.06 & 0.89 \\
Independent model & $6157.67^{* *}$ & 1540 & 3.99 & $-5100.42^{* *}$ & 0.50 & - & 0.09 & - \\
Two-factor model & $1476.49^{* *}$ & 402 & 3.67 & $-419.24^{* *}$ & 0.79 & 0.62 & 0.08 & 0.58 \\
One-factor model & $1556.62^{* *}$ & 403 & 3.86 & $-499.37^{* *}$ & 0.75 & 0.56 & 0.09 & 0.52 \\
\hline
\end{tabular}

Source: Elaborated by the authors.

Note:

$* * p<0.01$

The need for the separation of the variable "decisions in transition" into two variables, called "rational decisions" and "decisions that extrapolate rationality," was identified, and the contents of the variable "decisions" was verified. With this, it was possible to obtain the model with the best indicators $\mathrm{X}^{2}(393, \mathrm{~N}=357)=1057.25,\left(\mathrm{P} 0.01, \mathrm{X}^{2} / d f=2.70, \mathrm{GFI}=0.91, \mathrm{CFI}\right.$ $=0.90$, RMSEA $=0.06, \mathrm{TLI}=0.89$ ).

Following the recommendations of Hair Junior, Black, Babin et al. (2009) and Kline (2005), competing models were tested, in addition to the one proposed by the study. First, there was a comparison with the independent model. Then, a two-factor model was tested, in which the four factors attributed to career transition (drivers, decision, attributes, and resources) were grouped into one factor - the other referred to perception about the previous profession. On the other hand, the second model test grouped the five proposed factors into only one factor. Considering the satisfactory adjustment of the measurement model, the same strategy followed in the structural model of comparison with an adjusted model and another competitor. 
According to Table 3, the theoretically proposed model presented the following $X^{2}$ adjustment indices $(399, N=357) .=1025.70$, $\left(\mathrm{p} 0.01, \mathrm{X}^{2} / d f=2.57, \mathrm{GFI}=0.90, \mathrm{CFI}=0.88, \mathrm{RMSEA}=0.07, \mathrm{TLI}=0.87\right.$ ). However, in this model, no significant influence $(p<0.05)$ of the perception of transition drivers $(\beta=-0.04)$ were detected in the transition decision. For this reason, the model was adjusted, considering the driver factors as having an influence on perception about the previous profession, thus obtaining a positive influence in the latter, and better $X^{2}$ adjustment indexes $(398, N=357)=999.06, p 0.01, X^{2} / d f=2.51$, $\mathrm{GFI}=0.92, \mathrm{CFI}=0.90, \mathrm{RMSEA}=0.06, \mathrm{TLI}=0.89$.

Table 3

Structural statistical model

\begin{tabular}{lcccccccc}
\hline Tested structural models & $\chi^{2}$ & $d f$ & $\chi^{2} / d f$ & $\Delta \chi^{2}$ & GFI & CFI & RMSEA & TLI \\
\hline Proposed model & 1025.70 & 399 & 2.57 & - & 0.90 & 0.88 & 0.07 & 0.87 \\
Adjusted model & $999.06^{* *}$ & 398 & 2.51 & & 0.92 & 0.90 & 0.06 & 0.89 \\
Competitor model & $1431.69 * *$ & 403 & 3.55 & $* *$ & 0.78 & 0.63 & 0.08 & 0.59 \\
\hline
\end{tabular}

Source: Elaborated by the authors.

Note:

$* * p<0.01$

The competing model in which the transition decision influenced all the other variables (previous profession, attributes, impulses, and transition resources) presented the worst $\mathrm{X}^{2}$ indices $(357, \mathrm{~N}=800)=1.431 .67,\left(\mathrm{p} 0.01, \mathrm{X}^{2} / d f=3.55, \mathrm{GFI}=\right.$ $0.78, \mathrm{CFI}=0.63, \mathrm{RMSEA}=0.08, \mathrm{TLI}=0.59$ ). The most credible model was then considered among the tested ones and may be observed in Figure 1.

Figure 1

Adjusted structural model

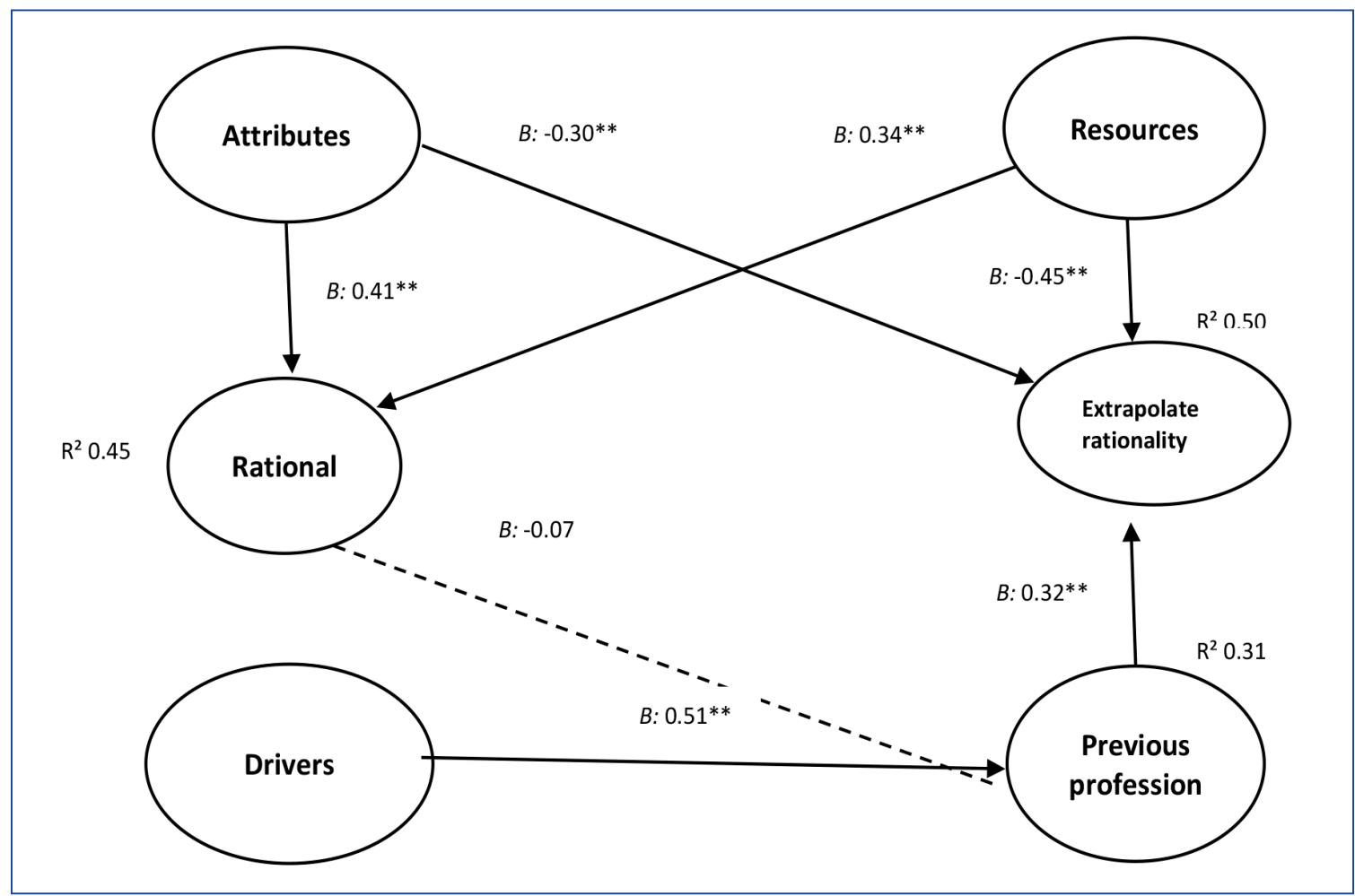

Source: Elaborated by the authors.

Note:

$* * p<0.01$ 
According to Hair Junior, Black, Babin et al. (2009, p. 609), "the results of confirmatory factor analysis suggest that relevant modifications should be reassessed with a new data set." For the purpose of reapplication and adjustments of the final instrument of the research and to verify the reliability of the results, the questionnaire, with its 29 statements validated in the main study, was applied again for a second sample of 100 professors.

The characteristics of this second sample were: an average age of 48 years; $96 \%$ were active in the State of São Paulo; $60 \%$ men and $40 \%$ women; $77 \%$ were engaged in more than one profession parallel to the teaching career, with a predominant area of administration (62\%). The means and standard deviations of the 29 statements allocated in the five variables were obtained and Cronbach's reliability indices were calculated, in which four of the five constructs were satisfactory, being close to or above the reference value of 0.7 .

\section{Analysis of hypotheses}

The results herein presented partially confirmed hypothesis 1 , that is, perception of the previous profession has a direct influence only on decisions that extrapolate rationality $(\beta=0.32, p<0.01)$. As Murtagh, Lopes and Lyons (2011) explained, this type of decision involves more subjectivity and has the context as something essential. Therefore, the view about the previous profession, if considered as a contextual factor in the transition, certainly influences the way the person feels about career changes, also affecting the most emotional forms of decision-making.

In hypotheses 3 and 4 , the transition attributes $(\beta=0.41, p>0.01)$ and the resources to deal with the transition $(\beta=0.34$, $p>0.01$ ) have positively influenced rational decisions in transition, however, presented a negative influence upon decisions that extrapolate rationality. In the analysis of these two hypotheses, it was possible to realize that the variation of transition situations affects the way in which the person makes his or her decisions. In this sense, Ashforth (2001) explained that transitions affect people in different ways, depending on the nature and on the attributes of change. Whereas Anderson, Goodman, and Schlossberg (2012) already stated that the individual always triggers resources to deal with the transition, from this analysis, it was possible to deduce that the positive attributes of the transition and the resources that the person brings to this moment also make the decisions more rational and probably more planned.

When analyzing the drivers of the transition, a direct positive influence on the perception about the previous $(\beta=0.51, p>$ 0.01 ) and an indirect positive $(\beta=0.16, p>0.01)$ about the decisions profession in transition was detected, when related to extrapolation of rationality. Therefore, it was only possible to partially confirm hypothesis 2 . The influence of the transition drivers on the perception of the previous profession and the influence of this vision on decisions that extrapolate rationality are a phenomenon that reveals that career frustration (MORISON, ERICKSON and DYCHTAWALD, 2006) and the perception about the context in which the transition took place (MURTAGH, LOPES and LYONS, 2011) have the potential to determine the occurrence of more subjective decisions in the transition, due to the emotional burden associated with certain work situations.

In general, it was found that there is direct influence of the previous profession, resources and attributes in the decisions that extrapolate rationality. Whereas the attributes $(\beta=-0.30, p>0.01)$ and the resources $(\beta=-0.45, p>0.01)$ positively affect rational decisions during the transition, however, they negatively influence decisions that extrapolate rationality.

\section{DISCUSSION OF RESULTS}

In this work, the association of inter-professional transition with the rationality of decisions allowed the construction of a model that demonstrates that the way in which inter-professional transition happens in terms of resources and attributes influences both rational decisions and those that extrapolate rationality. However, the perception of the previous profession influences decisions that extrapolate rationality more than rational decisions. It was possible to observe that the drivers have the indirect potential to explain the rationality of the decisions, since they interfere with the perception of the previous profession. It was then noted that frustrations with the previous profession drive people to make the transition, leading them to make fewer rational decisions.

This model clarifies the rationality of decision-making in the career transition and leads to the analysis that when people regard the situation of the previous profession with uncertainty, they tend to make more emotional decisions and are subject 
to contextual variations. However, by realizing that they have the necessary resources and by looking at the positive attributes of the transition, they can make more rational and less impulsive decisions.

The importance of rational career decisions has a great impact on the lives of people and is among the most important choices of an individual (JUNG, PARK and RIE, 2015; VERBRUGGEN and VOS, 2016). Based on the results of this research, it is possible to infer that the moment that the person experiences, both at work and outside of it, must be carefully evaluated in the planning of professional changes.

In terms of context, it has been noted that there are differences between the most recent and the oldest transitions. The perception of the previous profession more focused on the new organizational careers proposed by Clarke (2013) was more prevalent for the public with more recent transition. This result shows that the work scenario in Brazil no longer considers organizational careers in the traditional sense but tends to consider them in the direction of more flexible and less stable jobs. The university-level academic career then receives workers who no longer experienced stability in their previous profession.

The previous professional situation is related to the choice of the next profession and, especially, to the emotions that involve the process of career change, represented by the decisions that extrapolate rationality. As for this result, the guidelines of Clarke (2013) on the current situation of organizational careers show the importance of analyzing the career context that is to be left behind before deciding for change, checking the strengths and weaknesses of the working situation. The lack of evaluation of the reasons that led to the will to change and the negative view on the current professional situation can lead the person to make decisions driven by emotions, leading to future misunderstandings.

It was found that the youngest public, aged 25 to 40 years, as well as the professors with less education, had their profession change more driven by the sources of frustration described by Morison, Erickson and Dychtawald (2006). The results obtained can help to expand the age range of studies in the mid-career crisis and to reaffirm that such frustrations can be related to the worker's lack of investment in his or her professional training. It is possible to infer that younger workers are attracted to the academic career in Brazil because they experience in their previous professional situation involving imbalance between personal and professional life; lack of prospects; disappointment with their career; and exhaustion (MORISON, ERICKSON and DYCHTAWALD, 2006).

The fact that people with lower weekly working hours perceive more positively the attributes of the transition than those with higher working hours may indicate that the greater availability of time may favor the elaboration of a more structured transition planning. By associating the "time" with the resources analyzed by Anderson, Goodman and Schlossberg (2012), it is possible to suggest that, in order not to increase the difficulty inherent in career changes, a survey of the resources that will be activated in the transition process will be carried out. In addition to the financial ones, which need to be carefully analyzed, the psychological ones must not be neglected.

\section{CONCLUSIONS}

The study of transitions contributes to the understanding of the evolution of societies, their institutions, mobility, job redesign, and organizational change (NICHOLSON, 1984). Thus, it is important to understand a latent phenomenon in Brazil, which is the migration of people from other professions to university-level teaching (KILIMNIK, REIS NETO, SANTOS et al., 2015; FREITAS and FERNANDES, 2015).

The central objective of the research - to analyze the rationality of the decisions made by university professors in their transition from other professions to the teaching career - was accomplished by analyzing 357 responses to a questionnaire that was subsequently applied to a hundred new respondents. The statistical analyzes carried out allowed the understanding of several influences upon the rationality of inter-professional transitions.

From the analysis of hypotheses, it was possible to understand that career decisions involve several factors, some of them contextual. It is relevant to notice the fact that people who felt insecure about their previous profession tended to make transition decisions less rationality-oriented. It also represents an important research finding the result that people with a lower current workload felt more gratified by their decision to join the academic career. These data enabled us to identify risks of transitions based on the illusion that permeates certain professions and on the fear of losing employment. There 
are also risks for transitions leading to professions where the workload is excessive, because this characteristic of the new occupation has the potential to elicit some repentance regarding the change that has taken place.

The area of people management needs new studies that contribute to reconcile the objectives of professionals with the goals of the organization. This alignment depends, among other factors, on how much people feel cared for at their career moment. Considering that some of the professionals surveyed came from companies, and understanding what led these people to leave their jobs may help us to decipher this phenomenon of professional migration and to promote retention attitudes. So, the results about the drivers of the transition deserve attention, because in this research, they were based on the sources of frustration with the previous profession, determined by Morison, Erickson and Dychtawald (2006). At this point, it is possible to consider that there is a lower limit in the tolerance of people to deal with such frustrations today, because they have been a great driving force for professors who have recently made transitions.

For people, the results indicate the importance of undertaking an analysis of the transition situation itself (ASHFORTH, 2001), because desirable features of change - for example, the positive view that society has about that transition - have the potential to deliver more rational decisions. It is also essential to search for resources of self-knowledge, social support, situation analysis, and strategy definition (ANDERSON, GOODMAN and SCHLOSSBERG, 2012). These actions might favor the balance between rational decision-making and the more subjective decisions, because these resources stimulate the rationality of decisions. However, when they are not present, decisions tend to be more subjective, implying risks to the future of the person in the new profession.

The assessment in this research of the importance of the resources provided by the individual during the transition to more rational decision making indicates the need to plan this moment of the career. Despite the observation by Ibarra (2009) that the strategies for changes are not conventional and that the transition itself leads to self-knowledge; such planning is likely an important determinant of the success of a person in the new profession. For companies and career management professionals, the relevance of the allowance to professional guidance programs is emphasized as a support required for people to deal with transitions.

Today, there is a social appeal for professionals to build their careers more independently from organizations, but the ways through which people can make changes in their professional life are not clear. Understanding how some individuals have made career changes may help others to become more autonomous in their decisions, especially at critical moments in their careers. Recent studies show the importance that the issues studied in this research may have for career management (e.g. AYOOBZADEH, 2017; SKILTON and BRAVO, 2017). Thus, the association between transitions and decisions in a statistically tested conceptual model has the potential to contribute to the literature about these two themes.

As a limitation, since the research is classified as a cross-sectional study, it is not possible to accurately identify the occurrence of cause and effect between the situation of the respondent in the previous profession and his or her situation during the career transition. Therefore, it must be recognized that the results may have common method bias problems (PODSAKOFF, MACKENZIE and PODSAKOFF, 2003). For future studies, investigations about the specificities of the constructs discussed here are recommended, such as the analyses of the impacts of the different drivers (burnout, disillusionment with employer, work/life tension, etc.) on the rationality of the transition. In addition, interviews that allow a deeper understanding of the phenomena analyzed in this article are recommended. 


\section{REFERENCES}

ANDERSON, M. L.; GOODMAN, J.; SHLOSSBERG, N. K. Counseling adults in transition: linking schlossberg's theory with practice in a diverse world. New York: Springer Publishing Company, 2012.

ARTHUR, M. B.; ROUSSEAU, D. M. Introduction: the boundaryless career as a new employment principle. In: ARTHUR, M. B.; ROUSSEAU, D. M. (eds.). The boundaryless career: a new employment principle for a new organizational era. New York: Oxford, University Press, 1996. v. 1, p. 3-20.

ARTHUR, M. B.; INKSON, K.; PRINGLE, J. K. The new careers: individual action and economic change. London: Sage Publications, 1999.

ASHFORTH, B. A. Role transitions in organizational life: an IdentityBased Perspective. New Jersey: Lawrence Erlbaum Associates, 2001.

AYOOBZADEH, M. Does academic mentoring improve career decision making? Academy of Management: Proceedings, Vancouver, v. 2015, n. 1, Nov. 2017. Available at: <https://journals.aom.org/doi/ abs/10.5465/ambpp.2015.12822abstract>. Accessed on: Mar. 18, 2020.

BARLEY, S.; BECHKY, B.; MILLIKEN, F. The changing nature of work: careers, identities, and work lives in the $21^{\text {st }}$ Century. Academy of Management Discoveries, v. 3, n. 2, p. 111-115, 2017.

CLARKE, M. The organizational career: not dead but in need of redefinition. The International Journal of Human Resource Management, v. 24, n. 4, p. 684-703, 2013. Available at: <http://dx.doi. org/10.1080/09585192.2012.697475>. Accessed on: Mar. 18, 2020.

FREIRE, L. I. F.; FERNANDEZ, C. O professor universitário novato: tensões, dilemas e aprendizados no início da carreira docente. Ciência \& Educação, Bauru, v. 21, n. 1, p. 255-272, 2015. Available at: <http://dx.doi.org/10.1590/1516-731320150010016>. Accessed on: Mar. 18, 2020.

GATI, I. Making career decisions: A sequential elimination approach. Journal of Counseling Psychology, v. 33, n. 4, p. 408-417, 1986.

GATI, I.; ASHER, I. The PIC model for career decision-making: Prescreening, in-depth exploration and choice. In: LEONG, F. T. L.; BARAK, A. (eds.). Contemporary Models in Vocational Psychology: A Volume in Honor of Samuel Osipow. Mah-wah, NJ: Erlbaum, 2001. p. 7-54.

GELATT, H. B. Decision making: A conceptual frame of reference for counseling. Journal of Counseling Psychology, v. 9, p. 240-245, 1962.

GIL, A. C. Como elaborar projetos de pesquisa. 5. ed. São Paulo: Atlas, 2010.

HAIR, JUNIOR, J. F. et al. Análise multivariada de dados. 6. ed. Porto Alegre: Bookman, 2009.

HALL, D. T. Preface. In: HALL, D. T. et al. (Ed.). The career is dead: long live the career. San Francisco: Jossey-Bass Publishers, 1996.

HALL, D. T. Careers in and out of organizations. London: Sage Publications, 2002.

HARTUNG, P. J.; BLUSTEIN, D. L. Reason, intuition and social justice: Elaborating on Parsons's career decision-making model. Journal of Counseling Development, v. 80, n. 1, p. 41-47, 2002. Available at: <http://dx.doi.org/10.1002/j.1556-6678.2002.tb00164.x>. Accessed on: Mar. 18, 2020.
HORST, A. C. V. D.; KLEHE, U. C.; HEIJDEN, B. I. J. M. V. D. Adapting to a looming career transition: how age and core individual differences interact. Journal of Vocational Behavior, v. 99, p. 132-145, Apr. 2017.

IBARRA, H. Identidade de carreira: a experiência é a chave para reinventá-la. São Paulo: Editora Gente, 2009.

INSTITUTO DE ESTUDOS E PESQUISAS EDUCACIONAIS ANÍSIO TEIXEIRA - INEP. (2014). Resumo Técnico. Censo da Educação Superior 2014. Brasília, DF: INEP, 2016. 55 p. Available at: <http://bit.do/fuYBj>. Accessed on: July 01, 2017.

JANIS, I. L.; MANN, L. Decision Making: A Psychological Analysis of Conflict, Choice and Commitment. New York: Free Press; Macmillan, 1977.

JUNG, H.; PARK, I. J.; RIE, J. Future time perspective and career decisions: The moderating effects of affect spin. Journal of Vocational Behavior, v. 89, p. 46-55, 2015. Available at: <https://doi.org/10.1016/j. jvb.2015.04.010>. Accessed on: Mar. 18, 2020.

KAHNEMAN, D.; SLOVIC TVERSKY, A. Judgment Under Uncertainty: Heuristics and Biases. Cambridge, England: Cambridge University Press, 1982.

KATZ, M. A model for guidance for career decision making. Vocational Guidance Quarterly, v. 15, p. 2-10, 1966.

KILIMNIK, Z. M. et al. Representações, sobre carreira, atividade docente e competências: um estudo com mestrandos em administração. In: ENCONTRO DA ANPAD, 30., 2006, Salvador. Anais... Salvador: EnANPAD, 2006.

KILIMNIK, Z. M. et al. O significado do trabalho: um estudo com professores de administração em uma universidade. Revista Lugares de Educação, v. 5, n. 11, p. 3-27, 2015.

KLINE, R. B. Principles and practice of structural equation modeling. 2nd edition. New York: The Guilford Press, 2005.

KOSTAL, J. W. WIERNIK, B. M. A meta-analytic investigation of demographic differences in protean, boundaryless, and proactive career orientations. Career Development International, v. 22, n. 5, p. 520-545, 2017. Available at: <https://doi.org/10.1108/CDI08-2017-0139>. Accessed on: Mar. 18, 2020.

KRUMBOLTZ, J. D. Serendipity is not serendipitous. Journal of Counseling Psychology, v. 45, n. 4, p. 390-392, 1998.

LOUIS, M. R. Career transitions: varieties and commonalities. Academy of Management Review, v. 5, n. 3, p. 329-340, 1980.

MADDOX-DAINES, K. Mid-career as a process of discovery. Career Development International, v. 21, n. 1, p. 45-59, 2016.

MAREE, K. Creating a Sense of Hope: The Essence of Career Construction for Life Designing in a Developing Country Contex. In: POPE, M.; FLORES, L. Y.; PATRICK, J. R. (Eds.) The Role of Values in Carrers. Charlotte: IAP, 2014.

MORISON, R.; ERICKSON, T.; DYCHTWALD, K. A crise da meia carreira. Harvard Business Review, Mar. 2006.

MURTAGH, N.; LOPES, P. N.; LYONS, E. Decision making in voluntary career change: an other-than-rational perspective. The Career 
Development Quarterly, v. 59, n. 3, p. 249-263, 2011. Available at: <https://doi.org/10.1002/j.2161-0045.2011.tb00067.x>. Accessed on: Mar. 18, 2020.

NICHOLSON, N. A theory of work role transitions. Administrative Science Quarterly, v. 29, n. 2, p. 172-191, June 1984.

NICHOLSON, N.; WEST, M. Transitions, work histories, and careers. In: ARTHUR, M. B.; HALL, D. T.; LAWRENCE, B. S. (eds.). Handbook of career theory. Cambridge: Cambridge University Press, 1989.

OLIVEIRA, M. C.; MELO-SILVA, L. L.; COLETA, M. F. Pressupostos teóricos de Super: datados ou aplicáveis à psicologia vocacional contemporânea. Revista Brasileira de Orientação Profissional, v. 2, n. 1, p. 223-234, 2012.

OLIVEIRA, L. C. V.; KILIMNIK, Z. M.; OLIVEIRA, R. P. Da gerência para a docência: metáforas do discurso de transição. Revista Eletrônica de Administração, Porto Alegre, v. 19, n. 2, 2013.

PAIVA, K. C. M.; MELO, M. C. O. L. Competências profissionais docentes e sua gestão em universidades mineiras. In: ENCONTRO DE GESTÃO DE PESSOAS E RELAÇÕES DE TRABALHO DA ANPAD, 2., 2009, Curitiba. Anais... Curitiba: EnGPR, 2009.

PARSONS, F. Choosing a vocation. Boston: Houghton-Mifflin, 1909.

PERDUE, S. V.; REARDON, R. C.; PETERSON, G. W. Person-environment congruence, self-efficacy, and environmental identity in relation to job satisfaction: a career decision theory perspective. Journal of employment counseling, v. 44, n. 1, p. 29-39, 2007. Available at: <https://doi.org/10.1002/j.2161-1920.2007.tb00022.x>. Accessed on: Mar. 18, 2020.

PHILLIPS, S. D. Choice and change: convergence from the decisionmaking perspective. In: SAVICKAS, M. L.; R. W. LENT (eds.). Convergence in career development theories: Implications for science and practice. Palo Alto, CA: Davies-Black, 1994. p. 155-163.

PHILLIPS, S. D. Toward an expanded definition of adaptive decision making. The Career Development Quarterly, n. 45, p. 275-287, 1997.

PITZ, G. F.; HARREN, V. A. An analysis of career decision making from the point of view of information processing and decision theory. Journal of Vocational Behavior, v. 16, p. 320-346, 1980.

PODSAKOFF, P. M.; MACKENZIE, S. B.; PODSAKOFF, N. P. Common method biases in behavioral research: A critical review literature and recommended remedies. Journal of Applied Psychology, v. 88, n. 5, p. 879-903, 2003. Available at: <https://doi.org/10.1037/00219010.88.5.879>. Accessed on: Mar. 18, 2020.

SAVICKAS, M. L. Career adaptability: An integrative construct for life-span, life-space theory. The Career Development Quarterly, v. 45, p. 247-259, 1997.

SAVICKAS, M. L. Helping people choose jobs: A history of the guidance profession. In: ATHANASOU, J. A.; ESBROECK, R. V. (eds.). International Handbook of Career Guidance. New York: Springer, 2008. p. 97-113.

SELLTIZ, C.; WRIGHTSMAN, L. S.; COOK, S. W. Métodos de pesquisa nas relações sociais. São Paulo: Pedagógica e Universitária, 2007.

SIMON, H. A. A behavioral model of rational choice. Quartely Journal of Economics, v. 69, n. 1, p. 99-118, 1955. Available at: <https://doi. org/10.2307/1884852>. Accessed on: Mar. 18, 2020.

SKILTON, P. F.; BRAVO, J. Employment transition intention: opportunity, personality and the perception of risk. Academy of Management: Proceedings, Vancouver, v. 2015, n. 1, Nov. 2017. Available at: <https://doi.org/10.5465/ambpp.2015.13684abstract>. Accessed on: Mar. 18, 2020.

SUPER, D. E. The life span, life space approach to career development. In: BROWN, D.; BROOKS, L. (orgs.). Career choice and development. 2nd ed. San Francisco: Jossey-Bass, 1990. p. 197-261.

VELOSO, E. F. R. Carreiras sem fronteiras e transição profissional no Brasil: desafios e oportunidades para pessoas e organizações. São Paulo: Atlas, 2012.

VELOSO, E. F. R.; DUTRA, J. S. A tomada de decisões na transição de carreira: uma proposta de associação de conceitos. Revista Administração em Diálogo - RAD, v. 16, n. 2, p. 216-245, 2014 Available at: <http://dx.doi.org/10.20946/rad.v16i2.22723>. Accessed on: Mar. 18, 2020.

VELOSO, E. F. R.; DUTRA, J. S. Carreiras sem fronteiras na gestão pessoal da transição profissional: um estudo com ex-funcionários de uma instituição privatizada. Revista de Administração Contemporânea - RAC, Curitiba, p. 834-854, Sept./Oct. 2011.

VERBRUGGEN, M.; VOS, A. When people don't realize their career decisions: towards a theory of career inaction. Academy of Management Proceedings, Jan. 2016. (Meeting Abstract Supplement). Available at: <http://dx.doi.org/10.5465/AMBPP.2016.181>. Accessed on: Mar. 18, 2020. 


\section{Elza Fátima Rosa Veloso}

ORCID: https://orcid.org/0000-0002-9494-2108

Professor with a PhD and post-doctorate degree in business from the Universidade de Sao Paulo (FEA-USP); Master's degree in administration from the Pontifícia Universidade Católica de São Paulo (PUC-SP); Professor at the Fundação Instituto de Administração (FIA), where she works in the professional master's degree in Business Management, in the undergraduate course in administration and in the executive coordination of the Program of Studies in People Management (PROGEP); Professor at Universidade Prebisteriana Mackenzie, São Paulo - SP, Brazil. E-mails: elzav@fia.com.br; elzafrv@gmail.com

Joel Souza Dutra

ORCID: https://orcid.org/0000-0002-3098-3656

PhD in business; Professor in administration at the Universidade de Sao Paulo (FEA-USP), where he works in undergraduate and graduate courses; Coordinator and professor of the Program of Studies in People Management (PROGEP) at the Fundação Instituto de Administração (FIA), São Paulo SP, Brazil. E-mail: jdutra@usp.br

\section{Rodrigo Cunha da Silva}

ORCID: https://orcid.org/0000-0002-0730-7801

PhD, with postdoctoral degree in business by the Universidade de São Paulo (FEA-USP); Professor of the undergraduate courses and the professional master's degree in Food and Beverage Management at the Universidade Anhembi-Morumbi; Professor at the Fundação Instituto de Administração (FIA), São Paulo - SP, Brazil. E-mail: rdgcdasilva@gmail.com

Leonardo Nelmi Trevisan

ORCID: https://orcid.org/0000-0002-0914-3679

PhD in Political Science and a Master in Economic History from the Universidade de Sao Paulo (USP); Post-doctoral degree in Economics from the University of London; Full professor, acting in undergraduate and graduate courses at the Pontifíca Universidade Católica de Sao Paulo (PUC-SP); Professor at the Escola Superior de Propaganda e Marketing (ESPM), São Paulo - SP, Brazil. E-mail: Intrevisan@pucsp.br 


\section{APPENDIX}

Table A

Standardized factorial loads

\begin{tabular}{|c|c|}
\hline Statement & Factorial loads \\
\hline atrib.trans: The change was planned by me. & 0.86 \\
\hline imp.: I felt exhausted & 0.74 \\
\hline imp.: I felt disappointed with the employer. & 0.70 \\
\hline rec.: I have taken concrete steps to deal with the situation & 0.68 \\
\hline atrib.trans: The choice was mine & 0.62 \\
\hline rec.: I sought the necessary information to address the changes & 0.58 \\
\hline $\begin{array}{l}\text { prof. ant: My relationship with the employer was secondary for me to continue } \\
\text { in employment }\end{array}$ & 0.55 \\
\hline rec.: The reasons for the change were clear to me & 0.52 \\
\hline rec.: The transition took place within my limits of overshoot & 0.50 \\
\hline rec.: The change was consistent with my values & 0.50 \\
\hline prof.ant: I felt insecure professionally. & 0.50 \\
\hline rec.: I looked at the situation in an optimistic way & 0.50 \\
\hline d. rac: I considered all possible alternatives & 0.47 \\
\hline imp.: I wanted to better balance work with my personal life & 0.45 \\
\hline d. rac: I took attitudes that followed a logical sequence. & 0.43 \\
\hline imp.: My work was incompatible with the dreams I had in youth & 0.43 \\
\hline prof.ant: I thought about bringing about constant changes in my career & 0.42 \\
\hline rec.: I have taken attitudes to deal with the situation & 0.42 \\
\hline rec.: I was in control of the situation & 0.42 \\
\hline rec.: I supported people I could trust. & 0.41 \\
\hline rec.: The affection I received from the closest people was an important support & 0.40 \\
\hline d.rac: I thought long before acting & 0.40 \\
\hline After the change, I continued to be a person committed to my work & 0.38 \\
\hline I had all the resources I needed to make the change & 0.38 \\
\hline $\begin{array}{l}\text { By the age I had, I felt that my ability to be competitive in that profession was } \\
\text { running out }\end{array}$ & 0.36 \\
\hline $\begin{array}{l}\text { I believed that my employability in that profession was insufficient to work } \\
\text { until retirement }\end{array}$ & 0.35 \\
\hline I used the experience I had with similar changes to face the situation & 0.34 \\
\hline My studies were insufficient to grow in career & 0.32 \\
\hline The employer's investments in my career were indifferent to me & 0.32 \\
\hline I felt that my career had possibilities to change & 0.31 \\
\hline My spirituality helped me to face the situation & 0.31 \\
\hline I started to give more value to things not related to work & 0.28 \\
\hline I looked for activities that would help me deal with the stress of change & 0.28 \\
\hline
\end{tabular}




\begin{tabular}{lc} 
& Continue \\
\hline \multicolumn{1}{c}{ Statement } & Factorial loads \\
\hline The change was positive for me. & 0.28 \\
I only took attitudes that could bring me positive results & 0.25 \\
With or without promotions, I developed my career & 0.12 \\
The change was easy for me. & 0.11 \\
At the time, my personal life was quiet & 0.11 \\
He took advantage of the opportunities offered by the employer when they & 0.11 \\
corresponded to what I wanted for my career & 0.07 \\
My current profession causes more admiration to people & 0.06 \\
Other people went through the same change with me & 0.05 \\
I considered my feelings to take attitudes & 0.04 \\
What I do today is similar to what I did before & 0.04 \\
I used my creativity to take attitudes & -0.01 \\
I tried to conform to the situation & -0.03 \\
The time to adapt to the new profession was long & -0.12 \\
I considered the possibility to come back to work in the previous profession & -0.16 \\
I have interpreted the available information in my own way & -0.19 \\
I was in doubt if I was doing the right thing & -0.45 \\
d.ext.rac: I ignored the possibility of taking certain attitudes, even knowing that & -0.55 \\
they could bring good results & -0.58 \\
d.ext.rac: The help of my self-knowledge was small & -0.59 \\
d.ext.rac: I thought little about the consequences of what I was doing & -0.62 \\
d.ext.rac I have taken some action just to seize the opportunity & -0.70 \\
d.ext.rac: I have taken unconscious attitudes & -0.74 \\
d.ext.rac: I rejected the possibility of planning & \\
d.ext.rac: I have taken various attitudes by chance & \\
\hline
\end{tabular}

Source: Elaborated by the authors.

Note: atrib.trans $=$ Transition attributes $/ \mathrm{imp} .=$ Drivers $/ \mathrm{rec}=$ Resources $/$ prof.ant $=$ Previous profession $/ \mathrm{D} . \mathrm{rac}=$ Rational decisions $/$ d.ext.rac = Decisions that extrapolate rationality. 